\title{
Knowledge and conduct of pharmacists for dispensing of drugs in community pharmacies: a cross-sectional study
}

\author{
Tiago Marques dos Reis ${ }^{1, *}$, Camilo Molino Guidoni ${ }^{2}$, Edmarlon Girotto ${ }^{2}$, Ricardo Radigheri \\ Rascado $^{3}$, Patrícia de Carvalho Mastroianni' ${ }^{4}$ Joice Mara Cruciol ${ }^{2}$, Leonardo Régis Leira Pereira ${ }^{1}$
}

\begin{abstract}
${ }^{1}$ Pharmaceutical Sciences Department, Faculty of Pharmaceutical Sciences of Ribeirão Preto, University of São Paulo, Ribeirão Preto, SP, Brazil, ${ }^{2}$ Pharmaceutical Sciences Department, State University of Londrina, Londrina, PR, Brazil, ${ }^{3}$ Pharmaceutical Sciences Department, Federal University of Alfenas, Alfenas, MG, Brazil, ${ }^{4}$ Pharmaceutical Sciences Department, State University of São Paulo “Júlio de Mesquita Filho”, Araraquara, São Paulo, Brazil
\end{abstract}

\begin{abstract}
The objective of the study was to evaluate the knowledge of pharmacists and check their conduct in relation to dispensing of drugs. This is a cross-sectional study performed in four municipalities from South and Southeast of Brazil, which are reference in health national scenario and concentrate 73.6\% of national economic activity. Pharmacists who works in community pharmacies were invited to answer a questionnaire prepared by the authors of this study and validated. The main outcome measured was the pharmaceutical knowledge, rated according to the number of correct answers on that questionnaire prepared by the researchers, and professional conduct in relation to dispensing of drugs. The data collection occurred from September to December 2012 and the information obtained were tabulated in duplicate by two independent researchers for later analysis. 486 community pharmacies were visited but only 112 professionals participated in the study. Among the participants, 78.6\% $(\mathrm{n}=88)$ did not have adequate knowledge to perform the dispensing of drugs, despite this same number of pharmacists claiming to have participated in conferences and courses after graduation. The main sources of information on drugs used by participants have a low level of scientific evidence. The performance of non-employment related tasks reduces the time available for the care of medication users. In addition, the indiscriminate sale of antimicrobials and the sale of products other than health, mischaracterize the role of the pharmacist in the community pharmacy. There are gaps in the knowledge of professionals, limiting the satisfactory completion of dispensing of drugs. In addition, the excess of other duties and inadequate professional conduct compromise the promotion of the rational use of drugs.
\end{abstract}

Uniterms: Pharmacists/professional conduct. Medicines/dispensing Medicines/rational use. Community pharmacy.

O objetivo do presente estudo foi avaliar o conhecimento de farmacêuticos e verificar suas condutas em relação à dispensação de medicamentos. Trata-se de um estudo transversal realizado em quatro municípios das regiões sul e sudeste do Brasil, que são referência no cenário nacional de saúde e concentram 73,6\% da atividade econômica nacional. Farmacêuticos que trabalham em farmácias comunitárias foram convidados a responder um questionário elaborado pelos autores do presente estudo e validado. Os principais desfechos medidos foram o conhecimento farmacêutico, avaliado segundo o número de acertos em um questionário elaborado pelos pesquisadores, e a conduta dos profissionais durante a dispensação de medicamentos. Os dados foram coletados de setembro a dezembro de 2012 e as informações obtidas foram tabuladas em duplicata por dois pesquisadores para posterior análise. 486 farmácias comunitárias foram visitadas, mas apenas 112 profissionais participaram do estudo. Entre os participantes, 78,6\% $(\mathrm{n}=88)$ não tinham conhecimento satisfatório para realizar a dispensação de medicamentos, apesar de este mesmo número de farmacêuticos terem afirmado participar de congressos e cursos após a graduação. As principais fontes de informação sobre medicamentos utilizados pelos participantes possuem um baixo

\footnotetext{
*Correspondence: Tiago Marques dos Reis. Centro de Pesquisa em Assistência Farmacêutica e Farmácia Clínica. Faculdade de Ciências Farmacêuticas de Ribeirão Preto. Universidade de São Paulo, Bloco S, Sala 23A. Avenida do Café, s/n - 14040-903 - Ribeirão Preto - SP, Brazil. E-mail: tiagomarques_farmacia@yahoo.com.br
} 
nível de evidência científica. A realização de tarefas não diretamente relacionadas à profissão reduz o tempo disponível para o atendimento aos usuários de medicamentos. Além disso, a venda indiscriminada de antibióticos e a comercialização de produtos alheios à saúde descaracterizam o papel do farmacêutico na farmácia comunitária. Existem lacunas no conhecimento dos profissionais, o que limita a realização satisfatória de dispensação de medicamentos. Além disso, o excesso de atribuições e a conduta profissional inadequada comprometem a promoção do uso racional de medicamentos.

Unitermos: Farmacêuticos/conduta profissional. Medicamentos/ dispensação. Medicamentos/uso racional. Farmácia Comunitária.

\section{INTRODUCTION}

The dispensing of drugs is essential to the correct and safe use of drugs because the pharmacist is at the core of the pharmacotherapeutic process and makes this work an appropriate setting for health education and realization of pharmaceutical care (Correr, Otuki, 2013; Galato et al., 2008; Obreli-Neto et al., 2013).

Thus in Brazil, health legislation requires community pharmacies to have a pharmacist during the entire period of operation (Brasil, 1973, 2001, 2009) following recommendations by international standards bodies such as the International Pharmacy Federation (IPI, 1993), National Association of Pharmacy Regulatory Authorities (NAPRA, 2006) and the Pharmaceutical Society of Australia (PSA, 1999). These standards guide the activity of the pharmacist in countries such as the United States, Canada and Australia, giving them the duty to promote the health, self-care, the rational use of drugs (RUD) and the success of pharmacotherapy by meeting the needs of each patient.

However for the dispensing to be made with quality, guidelines that regulate the activity should not only exist. It is also necessary that the pharmacist has satisfactory knowledge regarding medications, pharmacotherapy, good practice in pharmacies and act in accordance with ethical principles, contributing to the simple act of delivery (Correr, Otuki, 2013; Farina, Romano-Lieber, 2009; Lucchetta, Mastroianni, 2010).

Nevertheless there are few studies that show how the pharmacist is prepared to undertake the dispensing. Based on these, the aim of this study was to assess the knowledge and conducts of pharmacists regarding dispensing of drugs in community pharmacies.

\section{METHODS}

\section{Study design and setting}

A cross-sectional study was performed with pharmacists who work in community pharmacies. Cross- sectional studies are useful to determine the prevalence in variables such as knowledge and pharmacists conducts, which can show how the pharmacist preparation to perform the dispensing of drugs is and allow the formulation of hypotheses that might be tested to improve the professional activity. It was considered as community pharmacy private institutions where pharmaceutical services, health care, and individual or collective health guidance are provide. In this context, it is performed in these establishments the dispensing of manufactured drugs, cosmetics, supplies and similar (materials, products, equipment or accessories whose use or application relates to health) (Brasil, 2014).

Data collection took place in the cities that met the following criteria: a) be located within $500 \mathrm{~km}$ from the research headquarters, Ribeirão Preto (São Paulo State, Brazil); b) have fewer than a million inhabitants; and c) have two higher education institutions with an undergraduate degree in Pharmacy, at least one public and one private to ensure sample homogeneity. Thus, Ribeirão Preto, Araraquara (São Paulo State), Londrina (Parana State) and Alfenas (Minas Gerais State), municipalities that together make up about a million and a half inhabitants (IBGE, 2014), were included in the study.

The addresses of the community pharmacies were obtained from the Alfenas Pharmacists Association and the Regional Pharmacy Boards (RPB) in the states of São Paulo and Paraná. Pharmacist associations are nonprofit organizations with the aim of common professional goals while RPB federal authorities are responsible for overseeing pharmaceutical activities in the states. The study followed the recommendations of STROBE Strengthening the Reporting of Observational Studies in Epidemiology (Malta et al., 2010).

\section{Data collection}

For data collection which was held from September to December 2012, it was used a self-administered questionnaire that was previously prepared for the authors of this study. The use of self-administered questionnaire 
has limitations such as the possible occurrence of memory biases and difficulties in the interpretation of questions. To prevent these limiting factors that could affect the results of the study, the questionnaire was previously validated and subsequently subjected to a pilot study. The validation process followed models described in the literature (Armando et al., 2012; Njilele et al., 2012; Traverso et al., 2007). First in this process, a review of the questionnaire by ten researchers with experience in dispensing was carried out. Subsequently, a panel of five university professors with experience in dispensing and health legislation also evaluated the questionnaire. In each of these steps the points raised were discussed among the researchers until there was consensus by modifying the questionnaire and then resent to reviewers for approval. Upon completion of validation, the pilot study was conducted with five pharmacists working in community pharmacies, ensuring the effectiveness and clarity of the questionnaire.

The questionnaire had 47 questions and was divided into three sections: demographic data, knowledge, and conduct. In the first section, objectives and subjective questions had as variables: age, gender, position held in the community pharmacy, working hours, remuneration, bonuses (sales commissions or other benefits received), education length and type of institution (public or private) from which the pharmacists had graduated. Regarding education, pharmacists should respond if they were experts (trained to work in industries or clinical analysis), non-licensed (pharmacists who completed the course in Pharmacy but not enabled to work in industries or clinical analysis), or generalists (academic mode established since 2002 which replaced the expert mode and aimed to prepare students to work in all areas of pharmaceutical knowledge, including dispensing and clinical monitoring of patients in the health system).

In turn, in the section on knowledge, the issues sought to highlight everyday situations in community pharmacies, pursuant to the following laws:

- Board Resolution (BR) $n^{\circ}$. 20/11: related to antimicrobials (Brasil, 2011);

- $\quad \mathrm{BR} \mathrm{n}^{\circ}$. 44/09: provides for good practice in pharmacies (Brasil, 2009);

- $\quad$ Resolution no. 596/14 of the Federal Council of Pharmacy (FCP) approves the Code of Pharmaceutical Ethics (CFF, 2014);

- $\quad$ Law n ${ }^{\circ}$.9787/99: Establishes generic medication (Brasil, 1999);

- $\quad$ Decree $n^{\circ} .344 / 98$ : regulates substances and medicinal products subject to special control (Brasil, 1998);

- Law $n^{\circ}$. 5991/73: provides for trade in medicines, supplies and similar (Brasil, 1973).
Knowledge for dispensing of drugs was evaluated through six objective questions with three answer options of which one option was correct. In each question was contemplated a situation involving aspects covered in the legislation listed above. Thus, by the number of correct answers, the knowledge of the participants was classified as unsatisfactory ( $0-2$ correct), regular (3-4 correct) and satisfactory (5-6 correct). The participation of pharmacists in continuing education activities (carried out after completion of graduation: conferences, short courses, enhancement, expertise, residence, master and/or doctorate) was also investigated. Moreover, the professionals had to tick which sources of information were most used about drugs: information sent by FCP and RPB, books with collections of leaflets produced by pharmaceutical companies, websites, scientific magazines, technical and scientific books or conversing with other professionals. Furthermore, they were asked about the possible difficulties for the proper conduct of dispensing of drugs.

Finally, the third section of the questionnaire had objective questions focused on those related to pharmaceutical conduct variables: frequency and time spent on bureaucratic activities and guidance for patients, how pharmaceutical indication is performed, how is providing the patient guidance, which activities not directly related to the pharmaceutical profession are conducted for the participant (issuing invoices, cleaning the establishment, replacing products on the shelves, opening and closing cash processing and sales) and if pharmacist is selling products other than health (biscuits, ice cream, hair dryers, soda, juice, energy drinks, insecticides).

\section{Study protocol}

All the community pharmacies of the four municipalities were visited by a single researcher during data collection which occurred on Monday through Saturday (except holidays) and during business hours. Community pharmacies which were excluded from the study were as follows: a) did not have the presence of the pharmacist even after a second visit to the establishment by the researcher (minimum interval of two hours between visits); b) manipulated standard or officinal formulas; c) not marketed or manufactured drugs, d) were not private companies.

At the time of collection the researcher first asked the owner or property manager permission to approach the pharmacist and on granting, the application was registered by signing a Statement of Informed Consent form (SIC). 
Pharmacists were asked to answer the questionnaire and sign the SIC form also when they accepted the invitation. The questionnaire was completed by the pharmacist in the presence of the researcher and without permission for consulting any other sources for information. After completion the questionnaire was deposited in an unmarked envelope, sealed and returned to the researcher to ensure the confidentiality of information provided by the pharmacist.

\section{Data analysis and ethical approval}

The data were double entered by two researchers in a database created by the software EpiInfo ${ }^{\mathrm{TM}}$ (version 7.1.5.3). Subsequently, the typed inputs were compared and discrepancies corrected. The processing and analysis were performed with the aid of the same program, calculating numerical summary measures as mean frequencies, which allowed concise and quantitative statements that characterized the population study (Pagano, Gauvreau, 2012). Association measurements were performed by chi-square test of Pearson or Fisher's exact. The level of significance was $5 \%$, ie, tests that showed $\mathrm{p}<0.05$ were considered significant. The independent and dependent variables tested are presented in the Table I.

The study was approved by the Research Ethics Committee in of the School of Pharmaceutical Sciences of Ribeirão Preto, University of São Paulo, opinion n ${ }^{\circ}$. 114.532 and CAAE 03872312.1.0000.5403.

\section{RESULTS}

There were 432 community pharmacies included in the study and in 112 the pharmacists agreed to answer the questionnaire (Figure 1). The main reasons for refusal were: insufficient number of employees in the establishment $(39.4 \%)$, lack of time $(35.9 \%)$, and the excess tasks to be performed (16.2\%). These same allegations were reported by $50.0 \%$ of the 14 owners or managers who explained the reasons for not allowing the approach to the pharmacist.

Most participants were women $(72.3 \%, \mathrm{n}=81)$, $48.2 \%(\mathrm{n}=54)$ were less than 30 years of age $($ mean $=33.4$, standard deviation $=8.6$ years $)$ and $41.1 \%(n=46)$ were generalists. Nearly one in five had satisfactory professional

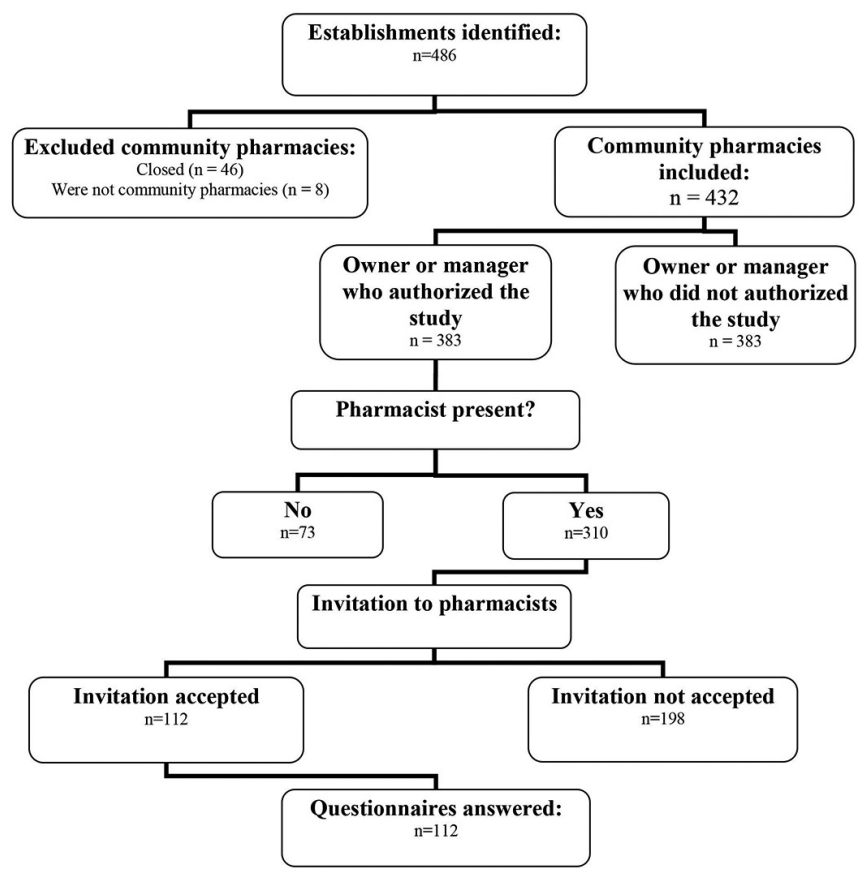

FIGURE 1 - Number of establishments involved in the stages of data collection.

TABLE I - Independents and dependents variables tested in the study

\begin{tabular}{ll}
\hline Independent variables & Dependent variables \\
\hline Type of institution & Knwledge \\
Type of institution & Misconduct on dispensing of drugs \\
Type of institution & Time spent on guidance of patients \\
Type of institution & Participation in continuing education activities \\
Knwledge & Time spent on guidance of patients \\
Generalists or not generalists & Knwledge \\
Difficulties to perform the dispensing of drugs & Knwledge \\
Difficulties to perform the dispensing of drugs & Time spent on guidance of patients \\
Participation in continuing education activities & Frequency on guidance of patients \\
Time of experience in dispensing of drugs & Knwledge \\
Time of experience in dispensing of drugs & Participation in continuing education activities \\
\hline
\end{tabular}


knowledge to perform the dispensing of drugs, with $62.5 \%$ $(\mathrm{n}=70)$ showing regular knowledge and $16.1 \%(\mathrm{n}=18)$, unsatisfactory. The number of correct and incorrect answers can be observed in Table II, which also shows that the question about dispensing of injection had the highest rate of errors. Eighty-eight pharmacists (78.6\%) participated in continuing education activities, but only $22.0 \%(n=18)$ of them had a satisfactory knowledge. The level of knowledge demonstrated by pharmacist for each type of continuing education activity carried out is shown in Figure 2.
A quarter of graduates from public universities had satisfactory knowledge. In turn, among the graduates in private educational institutions, less than $20.0 \%$ $(p=0.2533)$ showed satisfactory knowledge. Pharmacists trained by the private sector also showed more misconduct during dispensing $(\mathrm{p}=0.0737)$ and reported investing less time on the guidance of patients $(\mathrm{p}=0.0016)$. On the other hand, these professionals were those who more attended continuing educational $(\mathrm{p}=0.0356)$ activities.

Moreover, a slight tendency for pharmacists to

TABLE II - Profile of hits, errors and abstentions on issues that evaluated the pharmacists' knowledge for dispensing of drugs

\begin{tabular}{lccc}
\hline Question subject & $\begin{array}{c}\text { Correct } \\
\text { response } \\
\mathrm{n}(\%)\end{array}$ & $\begin{array}{c}\text { Incorrect } \\
\text { responses } \\
\mathrm{n}(\%)\end{array}$ & $\begin{array}{c}\text { No } \\
\text { responses } \\
\mathrm{n}(\%)\end{array}$ \\
\hline Disposal of medicines & $108(96.4)$ & $3(2.7)$ & $1(0.9)$ \\
Dispensing of anoretics & $96(85.7)$ & $9(8.1)$ & $7(6.2)$ \\
Dispensing of antimicrobials & $68(60.7)$ & $38(33.9)$ & $6(5.4)$ \\
Guidance on the use of medicines & $64(57.1)$ & $44(39.3)$ & $4(3.6)$ \\
Dispensing of medical products subject to special control & $42(37.5)$ & $64(57.2)$ & $6(5.4)$ \\
Dispensing of injectables & $21(18.8)$ & $89(79.4)$ & $2(1.8)$ \\
\hline
\end{tabular}

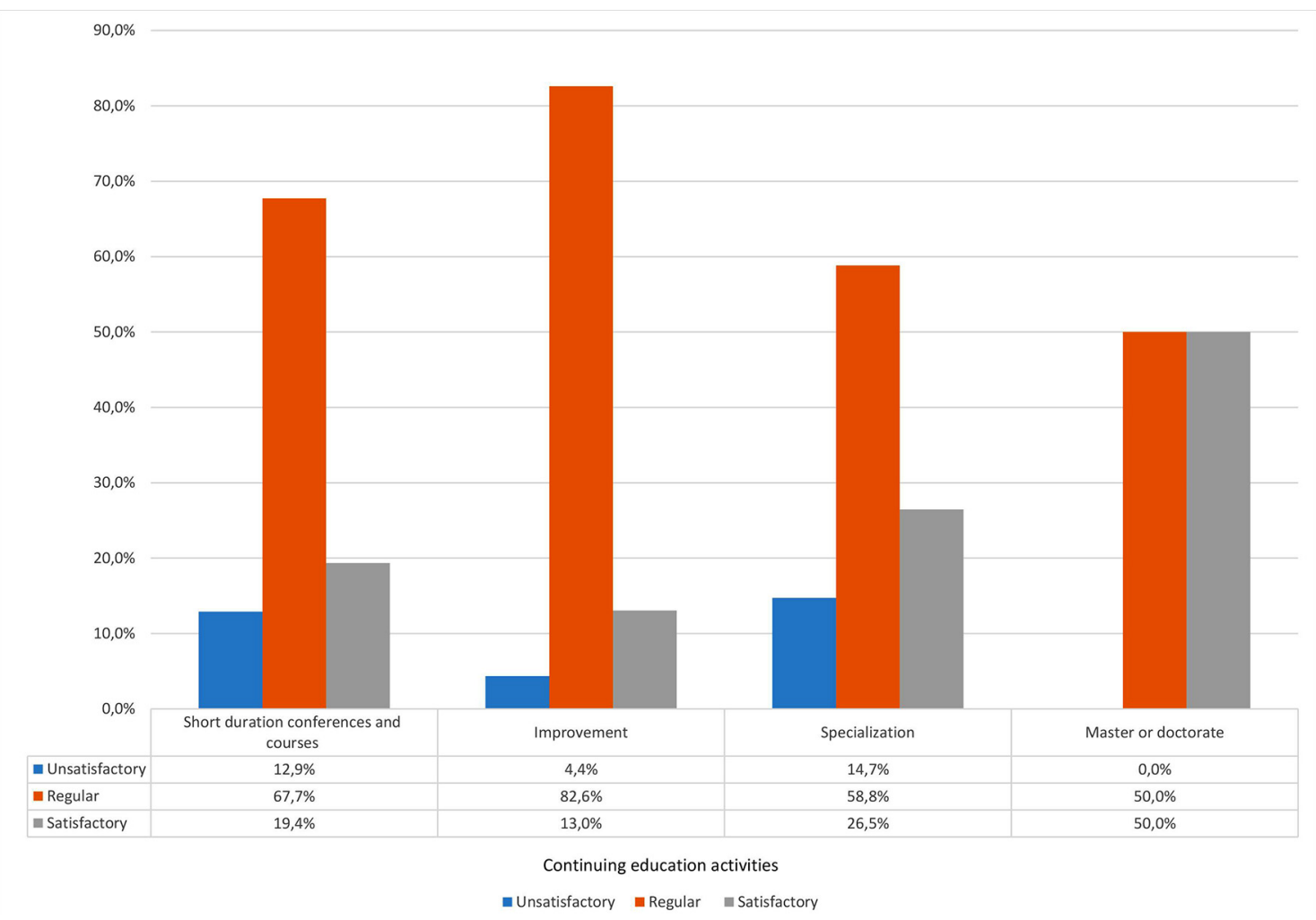

FIGURE 2 - Level of pharmacist knowledge for continuing education activity. 
reach the regular level of knowledge with increasing time of experience in dispensing was noticed $(\mathrm{r}=-0.0419)$ (Figure 3). There was no difference in knowledge between generalists and not generalists $(\mathrm{p}=0.7140)$.

The sources of drug information used by most participants are books such as the Remedies Guide, PR Vademecum ${ }^{\circledR}$ and the Dictionary of Pharmaceutical Specialties $(77.7 \%, \mathrm{n}=87)$; electronic collection of leaflets of the National Health Surveillance Agency and Martindale $(58.0 \%, \mathrm{n}=65)$; information sent by email by RPB and FCP $(58.9 \%, n=66)$; sites such as Google and Wikipedia $(55.4 \%, \mathrm{n}=62)$; exchanging information with professionals and representatives of the pharmaceutical industry $(45.5 \%, \mathrm{n}=51)$; technical and scientific journals and books $(24.1 \%, \mathrm{n}=27)$.

In turn, drug interactions $(36.6 \%, \mathrm{n}=41)$, adverse events $(21.4 \%, \mathrm{n}=24)$ and mechanisms of drug action $(20.5 \%, \mathrm{n}=23)$ were the main difficulties pointed out by professionals in guiding patients. The most prevalent justifications to explain them were lack of improvement activities $(22.3 \%, \mathrm{n}=25)$ and insufficient academic training $(15.2 \%, \mathrm{n}=17)$. It is important to highlight that $85.3 \%(n=64)$ of pharmacists with dispensing difficulties have unsatisfactory or regular knowledge $(p=0.0917)$ and that $58.8 \%$ of these professionals have undertaken specialization courses $(\mathrm{p}=0.9819)$. Accordingly, we observed that $49.1 \%(n=55)$ of professionals do not receive financial incentives for attending courses and interest in continuing education mainly occurs until the fifth year after graduation (Figure 4).

Pharmacists also reported that activities not directly related to the pharmaceutical profession are performed frequently during the workday $(55.4 \%, \mathrm{n}=62)$ and require little time to complete $(77.7 \%, \mathrm{n}=87)$. The frequency with which these activities performed affects the availability of the professional.

The dispensing of drugs frequently performed by $91.1 \%(\mathrm{n}=102)$ of participants is completed in a short time according to $46.4 \%(\mathrm{n}=52)$ of pharmacists. Accordingly, we observed that $96.8 \%(\mathrm{n}=91)$ of professionals without satisfactory knowledge responded that the guidance of patients at the counter demand little time $(\mathrm{p}=0.7528)$. In addition, it was noted that professionals who require more time in dispensing of drugs are those having difficulties to perform this service ( $p=0.0643$ ) while the pharmacists who participated in continuing education activities are those that give guidance more quickly ( $\mathrm{p}=0.7519)$. Approximately half of the participants do not usually guide or investigate aspects related to the safe use of drugs during dispensing.

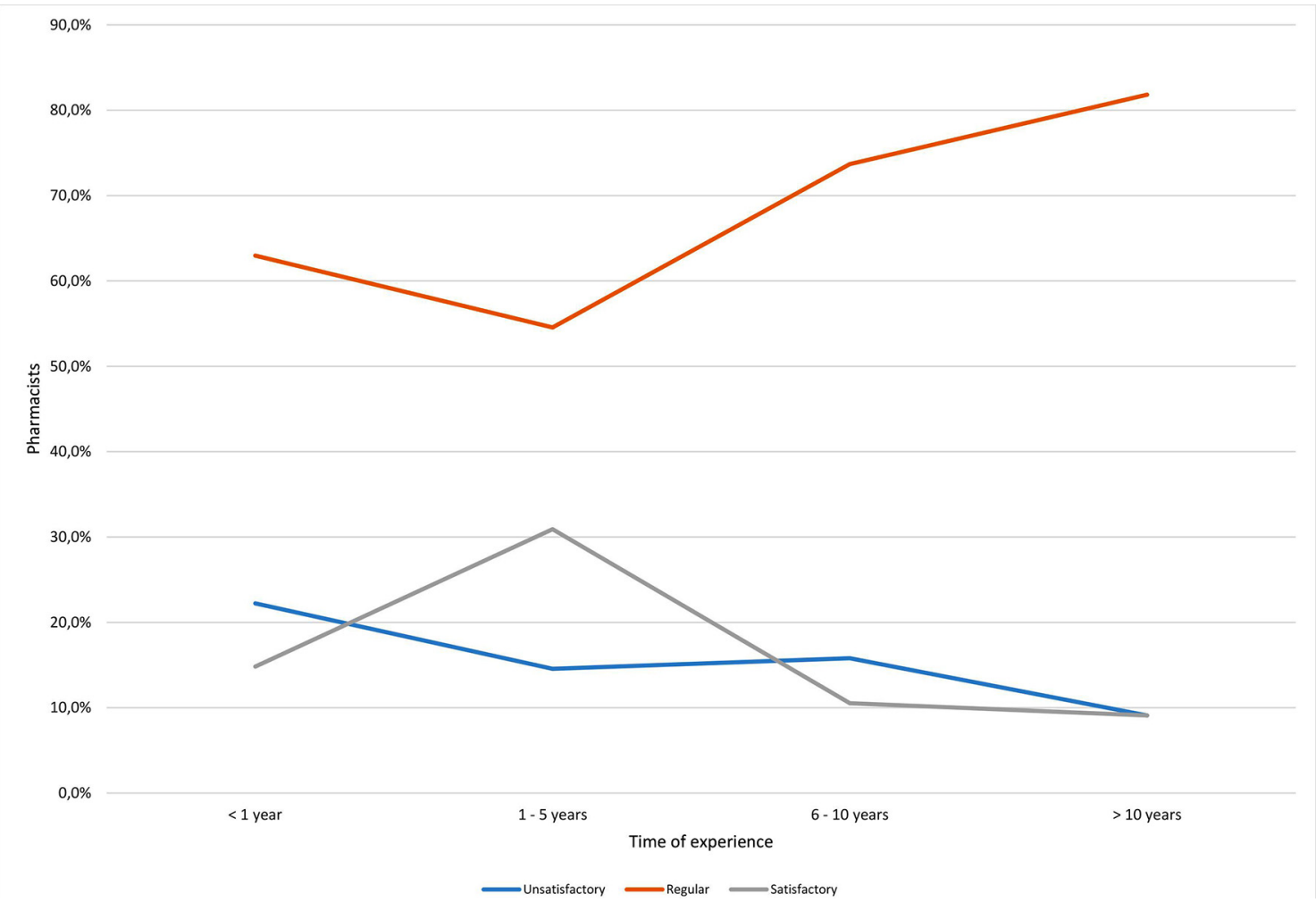

FIGURE 3 - Level of pharmacist knowledge for time of experience. 


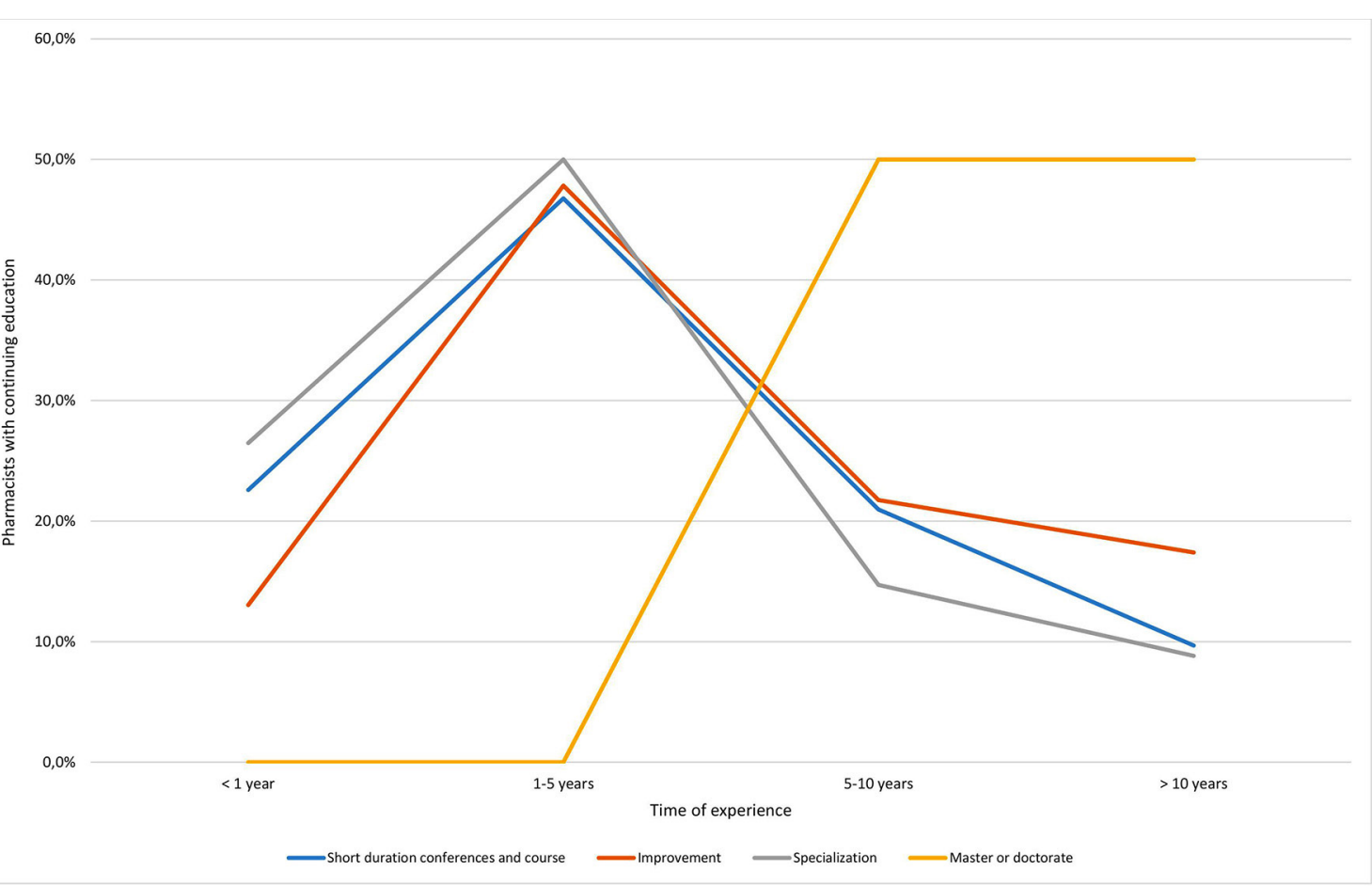

FIGURE 4 - Continuing educational activity for time of experience.

It was also stated that many pharmacists do not receive commission on the sale of drugs $(63.4 \%, n=71)$, or benefits such as food stamps and transportation vouchers $(54.6 \%, \mathrm{n}=61)$. However, the payment of these bonuses is more common in franchise community pharmacies $(64.2 \%, \mathrm{n}=34)$ than in independent pharmacies $(28.3 \%$, $n=15)$. It was also observed that $94.6 \%(n=105)$ of pharmacists have as their sole source of income earnings obtained in the community pharmacy.

The drug classes most suggested by pharmacists were: analgesics and antipyretics $(95.5 \%, \mathrm{n}=107)$, cold medicine $(93.8 \%, \mathrm{n}=105)$, multivitamins $(91.9 \%, \mathrm{n}=103)$, antacids/eupeptics/digestive enzymes $(91.1 \%, \mathrm{n}=102)$, antitussives $(88.4 \%, \mathrm{n}=99)$, antihistamines $(86.6 \%, \mathrm{n}=7)$ and anti-inflammatory agents in general $(82.1 \%, \mathrm{n}=92)$. It is noteworthy that there are pharmacists who indicate antimicrobials $(13.4 \%, \mathrm{n}=15)$, among which $83.3 \%(\mathrm{n}=5)$ did not have adequate knowledge and $66.7 \%(n=10)$ participated in continuing education activities. Apart from drugs, marketing products other than health was reported by 34 professionals $(30.4 \%)$.

\section{DISCUSSION}

The majority of participants were under 30 years of age, showing that the community pharmacy is the place that receives most pharmaceutical graduates in Brazil.
According to the FCP, the community pharmacy represent $85.5 \%$ of jobs for pharmacists (CFF, 2013) and so higher education institutions should provide appropriate training to improve the quality of service in these establishments. It is noteworthy that the number of pharmacies in Brazil is almost four times higher than recommended by the World Health Organization, highlighting the importance of community pharmacies in the health of the population (Zubioli, 1992).

However, almost $80 \%$ of the professionals have not demonstrated satisfactory knowledge to dispensing, presenting deficiencies in training because they had difficulty answering questions of the daily life of community pharmacies under health legislation. Studies conducted between 2004 and 2012 confirm these findings and emphasize the stagnation of pharmaceutical education in the country (Lucchetta, Mastroianni, 2010; Silva, Vieira, 2004; Tomassi, Ribeiro, 2012).

The high number of correct responses on the disposal of medicines is due to the National Solid Waste Policy and campaigns which raise awareness of professional (Brasil, 2010). However, misconceptions regarding the use of injectables may result from a lack of theory and practice obtained by working with patients (Mara, Bortoli, 2000; Fouche et al., 2014). Therefore, it is essential that the students of pharmacy courses should have contact with medication users during professional training. 
Considering the number of pharmacists with regular or unsatisfactory knowledge, it is evident that generalist academic mode needs to offer better training for pharmacotherapeutic follow up because almost $60 \%$ of the professionals in this category had a lack of ability to properly conduct this service (Tomassi, Ribeiro, 2012). Moreover, the similar knowledge performance shown by generalists and not generalists suggest that the change of the curriculum has not changed the profile of the pharmacist.

As is also observed in other studies, there was no significant difference in knowledge among graduates of public and private higher education institutions (Baldon et al., 2006; Lucchetta, Mastroianni, 2010). This highlights the need for reorientation of pharmacy training in both institutions. But associating this to the assertion that $77.6 \%$ of 416 pharmacy courses offered in Brazil have standard, medium, or low quality and that $28 \%$ of this total is not authorized by the Brazilian government to function (CFF, 2013), attests to the need to reform pharmaceutical education in the country.

In this context, the poor education offered at some private institutions encourages the pursuit of continuing education, since the graduates of these institutions, which make up $83.2 \%$ of pharmacists in the country (CFF, 2013), are the ones who then enroll in specialized courses often offered by private institutions. But the completion of the specialization is not able to make the professional fit for dispensing of drugs because $60.0 \%$ of specialists had difficulties in this activity. Similar results were observed in relation to the other activities of continuing education (Figure 2), reinforcing the importance of evaluating the quality of the training courses offered in the country. Insecurity and the lack pharmacist training discourage the promotion of RUD because technical knowledge and appropriate practices are essential for the guidance of patients (Angonesi, Rennó, 2011).

Allied to this condition, it was observed that the sources of information most used by pharmacists have low quality and almost no scientific grounding (Baldon et al., 2006; Heimann et al., 2013; Tomassi, Ribeiro, 2012). The English language limitations and lack of resources to acquire the right of access to well-known databases are elements that can justify the use of these information sources (Tomassi, Ribeiro, 2012). However, the lack of incentives from higher education institutions for students to seek information in primary secure and recognized scientific quality sources has a direct impact on the professional conduct of pharmacists.

Education should be based on constructionist teaching models, in which knowledge is the result of the interaction between the subject and object studied (Schindel, Given, 2013; Heimann et al., 2013). The concepts associated with academic experiences provide conditions for the theoretical content to be extrapolated in practical application, according to Miller (1990), and is the apex of the pyramid of education in health care. Thus, pharmacists acquire conditions and appropriate conduct, as well as learning to search for information from reliable sources in the search for answers to their questions, in order to become prepared for clinical action (Dewulf et al., 2009; Luccheta; Mastroianni, 2010; Silva, Vieira, 2004).

Still referring to pharmaceutical conduct, it was found that the activities not related to the pharmaceutical profession are performed frequently. The reverse situation is observed in countries like the United States where pharmacy assistants separate drugs while pharmacists are dedicated exclusively to the dispensing and monitoring of pharmacotherapy (Barros, 2000). In Brazil, pharmacists are responsible for carrying out bureaucratic activities (e.g., manage the marketing of medicinal products subject to special control as psychotropics, run and maintain record of pharmaceutical services offered at the pharmacy, and provide training to employees who work on the property) and so these professionals can not be fully available for dispensing of drugs. However, the fulfillment of tasks that do not relate to the field of pharmaceutical activities can overload the pharmacist and further reduce the time available for patient guidance. In addition, performing these activities also creates a sense of frustration within the profession (Oliveira et al., 2005), which in turn compromises the quality of services performed by the professional. Evidence of dissatisfaction and insecurity could be observed in professional discourse that justified the refusal of the invitation to participate in this study.

Moreover, participants responded that dispensing of drugs is often performed and requires little time to complete. It is considered that $81.5 \%$ of patients did not demonstrate satisfactory knowledge about the use of medication after a dispensing mean duration of up to 2.6 minutes (Oenning, Oliveira, Blatt, 2011). If we also consider other studies in which the average length of dispensing ranged between 18 and 53 seconds, it is seen that the quality of advice provided to the patient in a rapid dispensing may contribute to pharmacotherapeutic failure (Naves, Silver, 2005; Santos, Nitrini, 2004). The reported result also provides evidence that continuing education activities that have been carried out by pharmacists does not have enough quality to prepare them to dispensing of drugs. Thus, the gaps in knowledge may stimulate pharmacist to execute this service in a short period of time. 
The pharmacist is permitted to indicate medicine to users of the community pharmacy based on technical and scientific knowledge, ethical principles and resolutions issued by competent bodies (CFF, 2011). However, the lack of knowledge shown also highlights the unpreparedness for pharmaceutical indication. Moreover, as it is permissible for OTC drugs to treat health disorders with less complexity, antimicrobials cannot be among the indicated items (Santos, Nitrini, 2004). In this regard it is noteworthy that a federal resolution(Brasil, 2011) prohibits the marketing of antimicrobials without prescription but $40.0 \%$ of pharmacists are unaware of and violate this ruling. In other studies, this same behavior was observed among nearly half of professionals, which may hinder the identification of the risks of drug therapy, masking progressive diseases and promote bacteria resistance (Lucchetta, Mastroianni, 2010; Silva, Vieira, 2004; Tomassi; Ribeiro, 2012; Sallach-Ruma, Phan, Sankaranarayanan, 2013, Fatokun, 2014).

With respect to other behaviors such as receiving commission on the sale of drugs and the sale of non-health products in community pharmacies, it is emphasized that pharmacists are acting contrary to the ethical principles of the profession and to Brazilian health legislation. The receipt of commissions is a way to supplement the remuneration obtained since many pharmacists do not have another source of income and receive less than the minimum income for the profession. However, this practice serves as an incentive for selling products that patients don't need and represents an obstacle to the clinical performance of the pharmacist, this situation misplaces the pharmacist as a health professional (Farina, Romano-Lieber, 2009; Silva, Vieira, 2004). In turn, the sale of non-health products (including insecticides) suggests a deficiency of regulatory agencies as the exclusive marketing of medicines, supplies and related products for human use in community pharmacies (Brasil, 2009) is allowed. In addition, the sale of these products goes against efforts to re-characterize community pharmacies as health facilities, being that pharmacists are committed to changing the profile of community pharmacies since the laws are not enough to make this transformation possible.

In this context, it is important to highlight that a recently law published in 2014 determined that the government is responsible for guarantee the quality of actions taken in the context of pharmaceutical services (Brasil, 2014). This rule also established conditions to improve the fiscalization and the execution of pharmaceutical services in pharmacies. Therefore, once again the regulators organs try to organize the services offered in pharmacies. However, these efforts will not be enough while pharmacists have regular or unsatisfactory knowledge to perform tasks of their professional field (e.g., dispensing of drugs or other clinical services as pharmaceutical care), as well as ethical and legal conducts to promote the rational use of drugs.

Within the limitations of the study, it is recognized that the time required to complete the questionnaire may have curbed the participation of pharmacists, but the extent of the variables justifies the amount of questions. In addition, the limited number of participants may have compromised the statistical significance of the results, although the similarity between the pharmaceutical practices observed in the four municipalities serves as an indication that the problems found do not represent isolated regional contexts. In this sense it is worth mentioning that previous surveys conducted in different regions of Brazil (CFF, 2001; Farina, Romano-Lieber, 2009; Luccheta, Mastroianni, 2010; Nagassaki et al., 2002) revealed results similar to those demonstrated in this study. Furthermore, it is noteworthy that the four municipalities where the study was conducted are health references in the geographical areas where they are located and are representative of the national scene by having an average of 3.6 community pharmacies per 10,000 inhabitants (ratio similar to that of Brazil), gross domestic product per capita close to the national average and location in the south and southeast regions, in which $73.6 \%$ of the economic activity of the country is concentrated (IBGE, 2011).

\section{CONCLUSION}

Pharmacists do not have satisfactory knowledge for dispensing of drugs and show conduct that does not favor the RUD. A deficiency of education, the search for information on informal sources and lack of training limit the work of professionals.

Thus, it is necessary to restructure pharmaceutical education with a view to preparing the pharmacist to contribute to the success of pharmacotherapy. Furthermore, it is important to encourage the pursuit of professional qualifications and ensure the quality of courses offered to pharmacists to acquire knowledge to allow them to perform the role of a health professional.

\section{ACKNOWLEDGMENTS}

The authors thank the employees of the Pharmaceutical Services and Clinical Pharmacy Research Centre, School of Pharmaceutical Sciences of Ribeirão Preto, University of São Paulo. 


\section{REFERENCES}

ANGONESI, D.; RENNÓ, M.U.P. Dispensação farmacêutica: proposta de um modelo para a prática. Cienc. Saúde Coletiva, v.16, n.9, p.3883-3891, 2011.

ARMANDO, P.D.; PEREZ, S.R.M; GUERRA, A.C.M; PALLARES, M.M; UTHURRY, N.H.S; DADER, M.J.F. Desarrollo y validación de un cuestionario de satisfacción de pacientes con el seguimiento farmacoterapéutico en farmacias comunitarias. Rev. Calid. Asist., v.27, n.6, p.311$218,2012$.

BALDON, J. P.; CORRER, C. J.; MELCHIORS, A.C.; ROSSIGNOLI, P.; FERNANDEZ-LLIMOS, F.; PONTAROLO, R. Conhecimento e atitudes de farmacêuticos comunitários na dispensação de medicamentos para gestantes. Pharm. Pract., v.4, n.1, p.38-43, 2006.

BARROS, J.A.C. (Mis)information on drugs: the double standard practiced by pharmaceutical companies. $\mathrm{Cad}$. Saúde Pub., v. 12, n.2, p. 421-427, 2000.

BRASIL. LEI n ${ }^{\circ} .13021$, de 8 de agosto de 2014. Dispõe sobre o exercício e a fiscalização das atividades farmacêuticas. Diário Oficial da União, Brasília, DF, 11 de ago. 2014. Seção 1, p. 1.

BRASIL. Resolução $n^{\circ}$. 20, de 5 de maio de 2011. Dispõe sobre o controle de medicamentos à base de substâncias classificadas como antimicrobianos, de uso sob prescrição, isoladas ou em associação. Diário Oficial da União, Brasília, DF, 9 de mai. 2011. Seção 1, p. 94.

BRASIL. LEI n. ${ }^{\circ} 12.305$ de 02 de agosto de 2010. Institui a Política Nacional de Resíduos Sólidos. Diário Oficial da União, Brasília, DF, 03 ago. 2010. Seção 1, p.3.

BRASIL. Resolução da Diretoria Colegiada n. ${ }^{\circ} 44$ de 17 de agosto de 2009. Dispõe sobre Boas Práticas Farmacêuticas para o controle sanitário do funcionamento, da dispensação e da comercialização de produtos e da prestação de serviços farmacêuticos em farmácias e drogarias e dá outras providências. Diário Oficial da União, Brasília, DF, 18 ago. 2009. Seção 1, p.83.

BRASIL. Resolução da Diretoria Colegiada n. ${ }^{\circ}$ 357, de 20 de abril de 2001. Aprova o regulamento técnico das Boas Práticas em Farmácias. Diário Oficial da União, Brasília, DF, 27 abr. 2001. Seção 1, p. 24-30.
BRASIL. LEI n. ${ }^{\circ}$ 9.787, de 10 de fevereiro de 1999. Dispõe sobre a vigilância sanitária, estabelece o medicamento genérico, dispõe sobre a utilização de nomes genéricos em produtos farmacêuticos. Diário Oficial da União, Brasília, DF, 11 fev. 1999. Seção 1, p.1.

BRASIL. Ministério da Saúde. Portaria SVS/MS nº. 344, de 12 de maio de 1998. Aprova o regulamento técnico sobre substâncias e medicamentos sujeitos a controle especial. Diário Oficial da União, Brasília, DF, 19 mai. 1998. Seção 1, p. 37-49.

BRASIL. LEI n. ${ }^{\circ}$ 5.991, de 17 de dezembro de 1973. Dispõe sobre o controle sanitário do comércio de drogas, medicamentos, insumos farmacêuticos e correlatos. Diário Oficial da União, Brasília, DF, 19 dez. 1973. Seção 1, p.13049.

CONSELHO FEDERAL DE FARMÁCIA. CFF. Resolução n. ${ }^{\circ}$ 596, de 21 de fevereiro de 2014. Dispõe sobre o Código de Ética Farmacêutica, o Código de Processo Ético e estabelece as infrações e as regras de aplicação das sanções disciplinares. Diário Oficial da União, Brasília, DF, 25 mar. 2014. Seção 1, p. 99-103.

CONSELHO FEDERAL DE FARMÁCIA. CFF. I oficina sobre serviços farmacêuticos em farmácias comunitárias. Brasília: CFF, 2013.

CONSELHO FEDERAL DE FARMÁCIA. CFF. Resolução n. ${ }^{\circ} 546$, de 21 de julho de 2011. Dispõe sobre a indicação farmacêutica de plantas medicinais e fitoterápicos isentos de prescrição e o seu registro. Diário Oficial da União, Brasília, DF, 26 jul. 2011. Seção 1, p.87, 2011.

CONSELHO FEDERAL DE FARMÁCIA. CFF. Resolução n. ${ }^{\circ}$ 357, de 20 de abril de 2001. Aprova o regulamento técnico das Boas Práticas de Farmácia. Diário Oficial da União, Brasília, DF, 27 abr. 2001. Seção 1, p.24-30 , 2001.

CORRER, C.J.; OTUKI, M.F. A prática farmacêutica na farmácia comunitária. Porto Alegre: Artmed, 2013. ??? p.

DEWULF, N.L.; SANTOS, V.; PEREIRA, L.R.L.; TRONCON, L.E.A. The invisible pharmacist. Am. J. Pharm. Educ., v.73, n. 4, p. 74, 2009.

FARINA, S.S.; ROMANO-LIEBER, N.S. Drogarias: existe um processo de mudança? Saude Soc., v.18, n.1, p.7-18, 2009. 
FATOKUN, O. Exploring antibiotic use and practices in a Malaysian community. Int. J. Clin. Pharm., v.36, n.3, p.564-569, 2014.

FOUCHE, C.; KENEALY, T.; MACE, J.; SHAW, J. Practitioner perspectives from seven health professional groups on core competencies in the context of chronic care. $J$. Interprofessional, v.28, n.6, p.534-540, 2014.

GALATO, D.; ALANO, G.M., TRAUTHMAN, S.C.; VIEIRA, A.C. The dispensation of medicines: a reflection for prevention, identification and solution of drug related problems. Braz. J. Pharm. Sci., v.44, n.3, p.465-475, 2008.

HEIMANN, C.; PRADO, C.; MORAES, R.R.; VIDAL, G.V.; LIBERAL, D.; OLIVEIRA, G.K.; BARATA, M.V. Acquiring nursing knowledge through the constructivist method. Rev. Esc. Enferm. USP, v.47, n.4, p.997-1000, 2013.

INSTITUTO BRASILEIRODE GEOGRAFIAEESTATÍSTICA. IBGE. Cidades. Available at: $<$ http://cidades.ibge.gov.

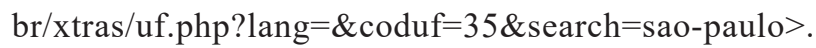
Accessed on: May 2014.

INSTITUTO BRASILEIRO DE GEOGRAFIA E ESTATÍSTICA. IBGE. Contas Nacionais. Rio de Janeiro: IBGE, 2011. 140 p.

INTERNATIONAL PHARMACEUTICAL FEDERATION. FIP. Standards for quality of pharmacy services. Good pharmacy practice. The Hague: FIP, 1993. Available at: <https://www.fip.org/files/fip/Statements/latest/ Dossier\%20004\%20total.PDF>. Accessed on: Sept. 2013.

LUCCHETTA, R.C.; MASTROIANNI, P.C. Avaliação do conhecimento e das condutas dos farmacêuticos, responsáveis técnicos por drogarias. J. Bas. App. Pharm. Sci., v.31, n3, p.183-191, 2010.

MALTA, M.; CARDOSO, L.O.; BASTOS, F.I.; MAGNANINI, M.M.; SILVA, C.M. STROBE initiative: guidelines on reporting observational studies. Rev. Saúde Publ., v.44, n.3, p.559-565, 2010.

MARA, R.S.; BORTOLI, C.S.H. Administração de medicamentos injetáveis por via intramuscular: conhecimento dos ocupacionais de farmácias. Rev. Esc. Enferm. USP, v.34, n.2, p.138-144, 2000.
MILLER, G.E. The assessment of clinical skills/competence/ performance. Acad Med., v.65, n.9, p.63-71, 1990. Suplemento.

NAGASSAKI, E.; FUKUDA, E.K.; YAMACITA, F.Y.; PEREZ, G.S.; CAMARGO, E.A.; SOUZA, J.M.C. Avaliação da Formação Acadêmica dos Farmacêuticos atuantes em Farmácias de Londrina-PR. Infarma., v.3, v.14, n.9/10, p.54-55, 2002.

NATIONAL ASSOCIATION OF PHARMACY REGULATORY AUTHORITIES. NAPRA. Model standards of practice for Canadian pharmacists. Ottawa: NAPRA, 2006.

NAVES, J.O.S.; SILVER, L.D. Avaliação da assistência farmacêutica na atenção primária no Distrito Federal. Rev. Saude Publ., v.39, n.2, p.223-230, 2005.

NJILELE, A.C.; UKWE, C.V.; OKONTA, J.M.; EKWUNIFE, O. I. Development of a patient satisfaction questionnaire for HIV/AIDS patients in Nigeria. Inter. J. Clin. Pharm. v.34, n.1, p.98-104, 2012.

OBRELI-NETO, P.R.; PEREIRA, L.R.L.; GUIDONI, C.M.; BALDONI, A.O.; MARUSIC, S.; LYRA-JUNIOR, D.P.; ALMEIDA, K.L.A.; PAZETE, A.C.M.; NASCIMENTO, J.D.; KOS, M.; GIROTTO, E.; CUMAN, R.K.N. Use of simulated patients to evaluate combined oral contraceptive dispensing practices of community pharmacists. Plos One, v.8, n. 12, p.e79875, 2013.

OENNING D.; OLIVEIRA, B.V.; BLATT, C.R. Conhecimento dos pacientes sobre os medicamentos prescritos após consulta médica e dispensação Patient awareness about drugs prescribed after medical appointment and prescription. Cienc. Saúde Coletiva, v.16, n.7, p.3277-3283, 2011.

OLIVEIRA, A.B.; OYAKAWA, C.N.; MIGUEL, M.D.; ZANIN, S.M.W.; MONTRUCCHIO, D.P. Obstáculos da Atenção Farmacêutica no Brasil. Rev. Bras. Cienc. Farm., v.41, n.4, p.409-413, 2005.

PAGANO, M.; GAUVREAU, K. Princípios de bioestatística. São Paulo: Cengage Learning, 2012. 522 p.

PHARMACEUTICAL SOCIETY OF AUSTRALIA. PSA. Standards for the provision of pharmacists only and pharmacy medicines in community pharmacies. Canberra: PSA, 1999. 
SALLACH-RUMA, R.; PHAN, C.; SANKARANARAYANAN, J. Evaluation of outcomes of intravenous to oral antimicrobial conversion initiatives: a literature review. Expert Rev. Clin. Pharmacol., v.6, n.6, p.703-729, 2013.

SANTOS, V.; NITRINI, S.M. Prescription and patient-care indicators in healthcare services. Rev. Saúde Publ., v.38, n.6, p.819-834, 2004.

SCHINDEL, T. J.; GIVEN, L.M. The pharmacist as prescriber: a discourse analysis of newspaper media in Canada. Res. Social Adm. Pharm., v.9, n.4, p.384-395, 2013.

SILVA, L.R.; VIEIRA, E.M. Pharmacists' knowledge of sanitary legislation and professional regulations. Rev. Saúde Publ., v.38, n.3, p.429-437, 2004.
TOMASSI, M.H.; RIBEIRO, E. Conhecimentos e atitudes de farmacêuticos em farmácias e drogarias do Butantã-São Paulo. J. Bas. App. Pharm. Sci., v.33, n.1, p.125-132, 2012.

TRAVERSO, M.L.; SALAMANO, M.; BOTTA, C.; COLAUTTI, M.; PALCHIK, V.; PEREZ, B. Questionnaire to assess patient satisfaction with pharmaceutical care in Spanish language. Int. J. Qual. Health C., v.19, n.4, p.217224, 2007.

ZUBIOLI, A. Profissão: farmacêutico. E agora?. Curitiba: Lovise, $1992.165 \mathrm{p}$.

Received for publication on $18^{\text {th }}$ November 2014 Accepted for publication on $09^{\text {th }}$ June 2015 